\title{
Pertanggungjawaban Hukum Ayah Terhadap Anak Setelah Terjadinya Perceraian
}

\author{
Barzah Latupono \\ Fakultas Hukum Universitas Pattimura, Ambon, Indonesia \\ E-mail: barzahlatupono75@gmail.com
}

\begin{tabular}{l}
\hline Info Artikel \\
\hline Keywords: \\
Legal Liability; \\
Fathers to Children; \\
Divorce. \\
\\
Kata Kunci: \\
Pertanggungjawaban \\
Hukum; Ayah \\
terhadap Anak; \\
Perceraian.
\end{tabular}

Abstract
Every marriage that is done there ends until death separates, but
there is also only a moment later divorced, divorce is a lot because
the husband remarries without permission of the wife and obligations
that the husband never did after divorcing his wife. After the
termination of the marriage according to the law the husband and
wife have the same duties and responsibilities in caring for and
supporting their children. However, in reality, every woman who has
been divorced by her husband will never again be supported by her
husband again even though he has children children who also need
money for their survival, and this father or ex-husband has never
been sanctioned if he does not provide maintenance and education
costs for his child, finally women often have to shoulder the burden
of responsibility to the child whose parental rights belong to him.
Abstrak
Setiap perkawinan yang dilakukan ada yang berakhir sampai maut
memisahkan namun ada juga yang hanya sesaat kemudian bercerai,
perceraian banyak dikarenakan suami menikah lagi tanpa ijin istri
dan kewajiban yang tidak pernah dilakukan suami setelah bercerai
dengan istri. Setelah putusnya perkawinan menurut Undang-
undang suami-istri itu mempunyai tugas dan tanggung jawab yang
sama dalam memelihara dan menafkahi anak-anaknya, Namun dalam
kenyataannya, setiap perempuan yang telah diceraikan oleh
suaminya tidak pernah lagi akan dinafkahi oleh suaminya kembali
walaupun dia mempunyai anak-anak yang juga membutuhkan biaya
untuk kelangsungan hidup mereka, dan bapak atau mantan suami ini
tidak pernah diberikan sanksi apabila tidak memberikan biaya
pemeliharaan dan pendidikan bagi anaknya akhirnya perempuan
sering harus memikul beban tanggungjawab kepada anak yang hak
pengasuhan berada padanya.

\section{A. PENDAHULUAN}

Bidang hukum yang seharusnya memberikan jaminan pemenuhan dan perlindungan terhadap hak asasi perempuan ternyata masih jauh dari harapan. Bahkan, sebaliknya banyak produk hukum yang menyudutkan perempuan. Berbagai fenomena menunjukkan 
betapa perempuan masih termarginalkan dan belum terakomodir penuh hak-haknya. Selain itu, ada perilaku seorang laki-laki yang boleh menikahi perempuan lain (poligami) atau isteri pertama diceraikan karena alasan suami untuk menikah lagi, yang membuat perempuan dan anak-anak merasa kecewa tak tahu harus bagaimana untuk kehidupan selanjutnya setelah dia diceraikan oleh suaminya Padahal anak-anak anggota keluarga dan dirinya memerlukan jaminan (makanan, sandang, papan, sekolah, biaya kesehatan dan biaya untuk mencari lapangan kerja).

Hal ini menunjukkan bahwa UUPerkawinan tidak efektif. Masih banyak laki-laki yang berpoligami tanpa memenuhi persyaratan yang ditentukan oleh undang-undang. Hal ini dikarenakan tidak ada sanksi yang tegas bagi pelaku yang melanggar ketentuan tersebut. Tidak hanya itu, menurut Pasal 4 ayat 3 UU Perkawinan pengadilan hanya akan memberi izin untuk berpoligami jika isteri tidak dapat menjalankan kewajibannya, isteri mendapat cacat badan atau penyakit yang tidak dapat disembuhkan, atau isteri tidak dapat melahirkan keturunan.Sedangkan dalam hal ini si isteri tidak memenuhi seluruh kriterianya. pada dasarnya pasal tersebut masih bias gender. bagaimana jika suami yang memiliki kekurangan sebagimana diatur dalam pasal tersebut

Biasanya setelah suami menikah lagi anak-anak tidak lagi diperhatikan, padahal hak-hak perempuan dan anak dalam bidang perkawinan baik itu semasa perkawinan itu masih berjalan maupun setelah perkawinan itu putus juga sudah diatur dalam UndangUndang Nomor 39 Tahun 1999 tentang Hak Asasi Manusia, yang memberikan perlindungan terhadap perempuan dalam perkawinan khususnya dalam Pasal 51 yaitu :

1) Seorang istri selama dalam ikatan perkawinan mempunyai hak dan tanggung jawab yang sama dengan suaminya atas semua hal yang berkenaan dengan kehidupan perkawinannya, hubungan dengan anak-anaknya, dan hak kepemilikan serta pengelolaan harta bersama;

2) Setelah putusnya perkawinan, seseorang wanita mempunyai hak dan tanggung jawab yang sama terhadap anak-anaknya, dengan memperhatikan kepentingan terbaik bagi anak;

3) Setelah putusnya perkawinan, seorang wanita mempunyai hak yang sama dengan mantan suaminya atas semua hal yang berkenaan dengan harta bersama tanpa mengurangi hak anak, sesuai dengan ketentuan perundang-undangan.

Setelah putusnya perkawinan suami-istri itu mempunyai tugas dan tanggung jawab yang sama dalam memelihara dan menafkahi anak-anaknya, Namun dalam kenyataannya, setiap perempuan yang telah diceraikan oleh suaminya tidak pernah lagi akan dinafkahi oleh suaminya kembali walaupun dia mempunyai anak-anak yang juga membutuhkan biaya untuk kelangsungan hidup mereka, dan bapak atau mantan suami ini tidak pernah diberikan sanksi apabila tidak memberikan biaya pemeliharaan dan pendidikan bagi anaknya akhirnya perempuan sering harus memikul beban tanggungjawab kepada anak yang hak pengasuhan berada padanya.

Berdasarkan latar belakang masalah di atas, maka rumusan masalah yang akan dikaji dalam penelitian ini adalah: "Pertanggungjawaban hukum terhadap hak asuh anak oleh ayahnya".

\section{B. PEMBAHASAN}

\section{Akibat Perkawinan}

Perkawinan mempunyai akibat terhadap tiga hal yaitu: 
a) Terhadap hak dan kewajiban suami istri dalam rumah tangga dan pergaulan di masyarakat.

Suami istri memikul tanggung jawab yang luhur untuk menegakan rumah tangga berdasarkan Ketuhanan Yang Maha Esa (Pasal 30). Hak dan kedudukan istri adalah seimbang dengan hak dan kedudukan suami dalam kehidupan rumah tangga dan dalam pergaulan hidup bersama dalam masyarakat (Pasal 31 ayat (1)). Masing-masing pihak berhak untuk melakukan perbuatan hukum (ayat 2). Suami adalah kepala keluarga dan istri sebagai ibu rumah tangga. Suami istri menentukan tempat kediaman mereka. Suami istri wajib saling cinta mencintai, hormat menghormati, saling setia. Suami wajib melindungi istrinya dan memberikan segala sesuatu sesuai dengan kemampuannya. Istri wajib mengatur urusan rumah tangga dengan sebaik-baiknya.

b) Hak yang sama atas harta yang dimiliki.

Selama perkawinan timbul harta bawaan dan harta bersama, suami atau istri masing-masing mempunyai hak sepenuhnya terhadap harta bawaan untuk melakukan perbuatan hukum apapun. Suami atau istri harus ada persetujuan bersama untuk melakukan perbuatan hukum terhadap harta bersama (Pasal 35 dan 36). Berdasarkan ketentuan Undang-Undang maka dapat disimpulkan bahwa apabila harta yang dibawah oleh para pihak masuk kedalam perkawinan, selama tidak dilakukan perjanjian untuk dijadikan sebagai harta bersama, maka harta tersebut tetap berada dibawah penguasaan masing-masing pihak, namun bila diperjanjikan untuk dijadikan sebagai harta bersama maka dalam penggunaannya harus atas persetujuan kedua belah pihak. Untuk harta bersama yang didapat setelah dilakukan perkawinan merupakan harta milik bersama walaupun dalam kenyataannya suami sendiri yang bekerja dan istri tidak tetapi harta yang di dapat suami merupakan harta bersama dengan istrinya.

c) Hak dan kewajiban dalam pemeliharaan anak.

Kedudukan anak: Anak yang dilahirkan dalam perkawinan adalah anak yang sah (Pasal 42); Anak yang dilahirkan di luar perkawinan hanya mempunyai hubungan perdata dengan ibunya dan kerabat ibunya saja.

Hak dan kewajiban antara orang tua dan anak: Kedua orang tua wajib memelihara dan mendidik anak-anaknya sampai anak-anak tersebut kawin dan dapat berdiri sendiri (Pasal 45); Anak wajib menghormati orang tua dan mentaati kehendaknya yang baik; Anak yang dewasa wajib memelihara orang tua dan keluarga dalam garis keturunan ke atas sesuai kemampuannya, apabila memerlukan bantuan anaknya (Pasal 46).

Kekuasaan orang tua: Anak yang belum berumur 18 tahun atau belum pernah kawin ada di bawah kekuasaan orang tua; Orang tua dapat mewakili segala perbuatan hukum baik di dalam maupun di luar pengadilan; Orang tua dapat mewakili segala perbuatan hukum baik di dalam maupun di luar pengadilan; Orang tua tidak boleh memindahkan hak atau menggadaikan barang-barang tetap yang dimiliki anaknya yang belum berumur 18 tahun atau belum pernah kawin.

Kekuasaan orang tua bisa dicabut oleh pengadilan apabila: mereka sangat melalaikan kewajibannya terhadap anak dan berkelakuan buruk sekali. Meskipun orang tua dicabut kekuasaannya, mereka tetap berkewajiban untuk memberi biaya pemeliharaan kepada anaknya. Orang tua wajib memelihara anak-anaknya sampai dewasa, walaupun kedua orang tua bercerai. Kewajiban orang tua harus tetap 
dilakukan berupa pemeliharaan dan pemenuhan hak anak baik itu pemenuhan dari segi ekonomi, pendidikan dan kasih sayang. Kewajiban orang tua ini dilakukan sampai anak itu dewasa atau sudah menikah dan mampu membiayai hidupnya sendiri.

\section{Kebijakan Pemerintah Dalam Rangka Perlindungan Hukum terhadap anak}

Menurut Huraerah, anak adalah setiap manusia yang belum berusia dibawah 21 tahun dan belum menikah, termasuk anak yang masih dalam kandungan. ${ }^{1}$ Pengertian anak secara hukum, diletakkan sebagai objek sekaligus subjek utama dalam suatu proses legitimasi, generalisasi dan sistematika aturan yang mengatur tentang anak.

Anak adalah amanah dan karunia Tuhan Yang Maha Esa yang dalam dirinya melekat harkat dan martabat sebagai manusia seutuhnya. Anak merupakan tunas, potensi, dan generasi muda penerus cita-cita perjuangan bangsa, memiliki peran strategis dan mempunyai ciri dan sifat khusus yang menjamin kelangsungan eksistensi bangsa dan negara di masa depan. Ketentuan Pasal 28B ayat (2) Undang-Undang Dasar Negara Republik Indonesia menyebutkan bahwa setiap anak berhak atas kelangsungan hidup, tumbuh dan berkembang serta berhak atas perlindungan dari kekerasan dan diskriminasi.

Undang-Undang Nomor 39 Tahun 1999 tentang Hak Asasi Manusia dalam Bab III Hak Asasi Manusia dan Kebebasan Dasar Manusia pada Bagian Kesepuluh mengatur mengenai hak anak. Bagian yang mempunyai judul Hak Anak ini memberikan ketentuan pengaturan yang dituangkan ke dalam 15 (lima belas) pasal, dimana dalam Pasal 52 ayat (2) disebutkan bahwa hak anak adalah hak asasi manusia dan untuk kepentingannya hak anak itu diakui dan dilindungi oleh hukum bahkan sejak dalam kandungan.

Negara Kesatuan Republik Indonesia dalam menjamin kesejahteraan pada setiap warga negaranya salah satunya adalah dengan memberikan perlindungan terhadap hak anak yang merupakan salah satu dari hak asasi manusia. Pemerintah Indonesia dalam usahanya untuk menjamin dan mewujudkan perlindungan dan kesejahteraan anak adalah melalui pembentukan Undang-Undang Nomor 35 Tahun 2014 tentang Perlindungan Anak. Perlindungan Anak tersebut adalah segala kegiatan untuk menjamin dan melindungi anak dan hak-haknya agar dapat hidup, tumbuh, berkembang, dan berpartisipasi secara optimal sesuai dengan harkat dan martabat kemanusiaan, serta mendapat perlindungan dari kekerasan dan diskriminasi.

Indonesia merupakan salah satu negara yang meratifikasi konvensi perserikatan bangsa - bangsa tentang hak anak, dan pula di sebutkan jika Indonesia menjamin terhadap pemenuhan dan perlindungan anak yang kemudian dalam pengimplementasiaanya pemerintah membuat kebijakan dengan mengeluarkan Undang - undang Nomor 35 tahun 2014. Dalam pengawasan terhadap hal tersebut pemerintah juga mendirikan lembaga Komisi Nasional Perlindungan anak dan Komisi perlindungan Perlindungan Anak Indonesia ( KPAI ).

Berbagai kebijakan yang dibuat pemerintah telah memberikan perlindungan terhadap anak baik dalam keluarga yang masih lengkap maupun setelah terjadi perceraian oleh kedua orang tuanya.

Didalam beberapa aturan Perundang-undangan dapat kita lihat beberapa hal yang mengatur kewajiban orangtua terhadap anak diantaranya, yaitu :

${ }^{1}$ Hurairah, A. (2006). Kekerasan Terhadap anak, Bandung: Penerbit Nuansa, h. 19. 
a) Kewajiban orangtua terhadap anak setelah perceraian menurut Undang-Undang perkawinan Nomor 1 Tahun 1974.

Secara hukum kewajiban antara suami dan istri akan timbul apabila perkawinan tersebut telah dilakukan atau dilangsungkan, dengan kata lain kewajiban seorang istri atau suami tidak akan ada apabila seorang pria atau wanita belum melangsungkan perkawinan. Adapun kewajiban dan hak yang seimbang antara suami maupun istri apabila dibarengi dengan kewajiban yang sama pula yaitu kewajiban untuk membina dan menegakkan rumah tangga yang diharapkan akan menjadi dasar dalam membangun rumah tangga. Kewajiban bersama antara suami dan istri dalam membina dan menjalin rumah tangga akan luntur apabila rumah tangga yang dibangun tersebut mengalami goncangan dan terlebih parahnya lagi apabila tatkala rumah tangga tersebut bubar.

Di dalam Pasal 45 disebutkan sebagai berikut: "kedua orang tua wajib memelihara dan mendidik anak-anak mereka sebaik-baiknya". Ayat (2) menyebutkan "kewajiban orang tua yang dimaksud dalam ayat (1) Pasal ini berlaku sampai anak itu kawin atau dapat berdiri sendiri, kewajiban mana berlaku terus meskipun perkawinan antar kedua orang tua putus".

Jadi secara rinci hak dan kewajiban orang tua terhadap anak dapat dijelaskan sebagai berikut: Memberikan perlindungan; Memberikan pendidikan; Mewakili anak dalam segala perbuatan hukum bagi yang umurnya delapan belas tahun kebawa dan belum pernah kawin; Memberikan biaya pemeliharaan anak walaupun kekuasaan orang tua telah dicabut.

Menurut pasal ini berarti orang tua mempunyai kewajiban memelihara dan mendidik anak dengan sebaik-baiknya. Bila orang tua tidak melaksanakannya atau orang tua berlaku buruk terhadap anak, maka orang tua dapat dicabut kekuasaannnya.

Apabila mereka dicabut kekuasaannya maka akan timbul perwalian terhadap anak sesuai dengan ketentuan Pasal 50 Undang-undang Perkawinan, yaitu ayat (1) "anak yang belum mencapai umur delapan belas tahun atau belum pernah melangsungkan perkawinan, yang tidak berada dibawah kekuasaan orang tua, berada dibawah kekuasaan wali". Ayat (2), menyatakan "perwalian itu mengenai pribadi anak yang bersangkutan maupun harta bendanya".

Sedangkan mengenai pemeliharaan kekayaan si anak diatur dalam Pasal 48 Undang-undang Perkawinan yang menyebutkan "orang tua tidak diperbolehkan memindahkan hak atau menggadaikan barang-barang tetap yang dimiliki anaknya yang belum berumur delapan belas tahun atau belum pernah melangsungkan perkawinan, kecuali anak itu menghendakinya". Pasal ini bertujuan untuk memberikan perlindungan terhadap barang tetap milik anak dari perbuatan orang tua yang mungkin dapat merugikan anak tersebut.

Orang tua harus bertanggung jawab dalam menjalankan kewajibannya untuk menjaga dan mencintai anak dengan penuh kasih sayang. Sehingga tercipta anakanak yang berbakti kepada orang tuanya. Jangan sampai orang tua menjadi durhaka kepada anaknya, dan juga sebaliknya.

Dari beberapa penjelasan UU di atas, maka dapat disimpulkan bahwa UU Perkawinan mengatur kewajiban orang tua terhadap anak-anaknya sekalipun rumah tangga telah putus karena perceraian. Kewajiban orangtua tersebut meliputi : 
a) Orangtua wajib memelihara dan mendidik anak-anak mereka sebaik-baiknya;

b) Orangtua mewakili anak mengenai perbuatan hukum di dalam dan diluar pengadilan;

c) Dalam Pasal 41 UU Perkawinan dijelaskan bapak bertanggung jawab atas semua biaya pemeliharaan dan pendidikan yang diperlukan anak, bilamana bapak dalam kenyataannya tidak dapat memenuhi kewajibannya, pengadilan dapat menentukan bahwa ibu ikut memikul biaya pemeliharaannya dan pendidikan yang diperlukan anak, Kewajiban tersebut tetap berlaku meskipun kekuasaan sebagai orangtua dicabut.

b) Kewajiban orang tua terhadap anak setelah perceraian menurut Kompilasi Hukum Islam.

Dalam pandangan ajaran Islam terhadap anak menempatkan anak dalam kedudukan yang mulia. Anak mendapatkan kedudukan dan tempat yang istimewa dalam Nash Al-Qur'an dan Al-Hadist. Karena itu di dalam pandangan Islam anak itu harus diperlakukan secara manusiawi, diberikan pendidikan, pengajaran, keterampilan dan akhlakul karimah agar anak tersebut kelak dapat bertanggung jawab dalam mensosialisasikan diri untuk memenuhi kebutuhan hidup dimasa depan.

Didalam KHI ketentuan-ketentuan yang mengatur tentang kewajiban orang tua terhadap anak Berkaitan dengan kewajiban orang tua setelah putusnya perkawinan, KHI dalam pasal- pasalnya menggunakan istilah dengan namanya pemeliharaan anak yang dimuat di dalam Bab XIV Pasal 98 sampai dengan Pasal 106, tetapi secara eksplisit pasal yang mengatur kewajiban pemeliharaan anak jika adanya perceraian hanya terdapat didalam Pasal 105 dan Pasal 106.

Mengenai hak dan kewajiban orang tua terhadap anaknya, menurut Kompilasi Hukum Islam (KHI) Pasal 105 (a) yang disebut Hadhanah. Hadhanah dalam ilmu fiqh adalah istilah bagi pemeliharaan anak diwaktu kecil baik laki-laki maupun perempuan atau yang belum sempurna akalnya serta belum baliq dan belum dapat berusaha sendiri. ${ }^{2}$ Kewajiban ini merupakan kewajiban orang tua baik dikala suami isteri masih utuh ataupun bercerai. Masalah Hadhanah ini tidaklah semata-mata berlaku untuk kedua orang tua saja, akan tetapi kerabat pun dapat ditugaskan melakukan hal tersebut apabila kedua orang tua anak itu tidak mampu atau dianggap tidak cakap.

Sedangkan menyangkut harta yang dimiliki anak, orang tua berkewajiban untuk merawat dan mengembangkan harta tersebut, hal ini diatur di dalam Pasal $106 \mathrm{KHI}$ yang menyebutkan :

1) Orang tua berkwajiban merawat dan mengembangkan harta anaknya yang belum dewasa atau masih dibawah pengampuan dan tidak diperbolehkan memindahkan atau menggadaikan kecuali karena keperluan yang sangat mendesak jika kepentingan dan kemaslahatan anak itu menghendaki atau sesuatu kenyataan tidak dapat dihindarkan lagi;

2) Orang tua bertanggung jawab atas kerugian yang ditimbulkan karena kesalahan dan kelalaian dari kewajiban tersebut pada ayat (1).

Pasal-Pasal yang terdapat dalam KHI tentang Hadhanah menegaskan bahwa kewajiban pengasuhan material dan non material kepada anak merupakan hal yang tidak dapat dipisahkan satu dengan yang lainnya. Lebih lagi KHI membagi tugas

2 Syarifuddin, A. (2006). Hukum Perkawinan Islam di Indonesia, Jakarta: Prenada Media, h. 327. 
yang harus dilakukan orangtua sekalipun mereka telah berpisah. Anak yang belum mumayyiz tetap diasuh oleh ibunya sedangkan pembiayaan tetap menjadi tanggung jawab dan kewajiban dari ayah. KHI juga menentukan anak yang belum mumayyiz atau belum berumur 12 (dua belas) tahun adalah hak bagi ibu untuk memeliharanya, sedangkan apabila anak tersebut sudah mumayyiz ia dapat memilih antara ayah atau ibunya untuk bertindak sebagai pemeliharanya.

\section{Pertanggungjawaban hukum orang tua terhadap anak setelah perceraian}

Anak merupakan persoalan yang selalu menjadi perhatian berbagai elemen masyarakat, bagaimana kedudukan dan hak-haknya dalam keluarga dan bagaimana seharusnya ia diperlakukan oleh kedua orang tuanya, bahkan juga dalam kehidupan masyarakat dan negara melalui kebijakan-kebijakannya dalam mengayomi anak. Ayah kandung berkewajiban memberikan jaminan nafkah anak kandungnya dan seorang anak begitu dilahirkan berhak mendapatkan nafkah dari ayahnya baik pakaian, tempat tinggal, dan kebutuhan-kebutuhan lainnya meskipun perkawinan orangtua si anak telah putus.

Bagi anak-anak yang dilahirkan, perceraian orang tuanya merupakan hal yang akan mengguncang kehidupannya dan akan berdampak buruk bagi pertumbuhan dan perkembangannya, sehingga biasanya anak-anak adalah pihak yang paling menderita dengan terjadinya perceraian orang tuanya. ${ }^{3}$

Landasan kewajiban ayah menafkahi anak selain karena hubungan nasab juga karena kondisi anak yang belum mandiri dan sedang membutuhkan pembelanjaan, hidupnya tergantung kepada adanya pihak yang bertanggung jawab menjamin nafkah hidupnya. Orang yang paling dekat dengan anak adalah ayah dan ibunya, apabila ibu bertanggung jawab atas pengasuhan anak di rumah maka ayah bertanggung jawab mencarikan nafkah anaknya. ${ }^{4}$ Ayah hanya berkewajiban menafkahi anak kandungnya selama anak kandungnya dalam keadaan membutuhkan nafkah, ia tidak wajib menafkahi anaknya yang mempunyai harta untuk membiayai diri sendiri. Sebaliknya anak keturunan sudah semestinya berbuat baik dan berkhidmat kepada orang tuanya secara tulus, orang tualah yang menjadi sebab terlahirnya ia ke dunia.

Jika digolongkan hak anak dapat dikategorikan kedalam empat kelompok besar, yaitu hak untuk hidup, hak untuk tumbuh dan berkembang, hak untuk mendapat perlindungan, dan hak untuk berpartisipasi. Dalam ajaran Islam, ada dua periode perkembangan anak dalam hubungannya dengan hak asuh orang tua, yaitu periode sebelum mumayyiz (anak belum bisa membedakan antara yang bermanfaat dan yang berbahaya bagi dirinya, dari lahir sampai berumur tujuh atau delapan tahun) menurut Kompilasi Hukum Islam sampai berusia 12 tahun, (Pasal $106 \mathrm{KHI}$ ), dan sesudah mumayyiz. Sebelum anak mumayyiz, ibu lebih berhak menjalankan hak asuh anak karena ibu lebih mengerti kebutuhan anak dengan kasih sayangnya apalagi anak pada usia tersebut sangat membutuhkan hidup di dekatnya. ${ }^{5}$

Masa mumayyiz dimulai sejak anak secara sederhana sudah mampu membedakan mana yang berbahaya dan bermanfaat bagi dirinya, ini dimulai sejak umur 7 (tujuh) tahun sampai menjelang dewasa (balig berakal). Pada masa ini anak sudah dapat memilih dan memutuskan apakah akan memilih ikut ibu atau ayahnya. Tetapi dalam kondisi tertentu

\footnotetext{
3 Zein, S. E. M. (2004). Problematika Hukum Keluarga Islam Kontemporer, Jakarta: Prenada Media, h. 98 .

4 Saifullah. (1999). "Problematika Anak dan Solusinya", Jurnal Mimbar Hukum, h. 48.

5 Satria Effendi. Ibid, h. 181.
} 
ketika pilihan anak tidak menguntungkan bagi anak, demi kepentingan anak hakim boleh mengubah putusan itu dan menentukan mana yang maslahat bagi anak.

Perceraian merupakan momok menakutkan bagi setiap keluarga (suami, istri, dan anak-anak). Penyebab perceraian bisa bermacam-macam, yaitu antara lain: gagal berkomunikasi, ketidaksetiaan, kekerasan dalam rumah tangga, masalah ekonomi, pernikahan usia dini, perubahan budaya, dan lain sebagainya.

Pasca perceraian ada penyesuaian-penyesuain yang harus dilakukan oleh kedua belah pihak (mantan suami dan mantan istri) terhadap kehidupan mereka yang baru. Terutama masalah finansial, apalagi dari perkawinan antara mereka telah dilahirkan anak.

Pasal 9 UU No.4 Tahun 1979 tentang kesejahteraan anak menyebutkan bahwa orangtua adalah yang pertama-tama bertanggung jawab atas terwujudnya kesejahteraan anak baik secara fisik, jasmani maupun sosial. Tanggung jawab orangtua atas kesejahteraan anak mengandung kewajiban memelihara dan mendidik anak sedemikian rupa, sehingga anak dapat tumbuh dan berkembang menjadi orang yang cerdas, sehat, berbakti kepada orangtua, berbudi pekerti luhur, bertakwa kepada Tuhan Yang Maha Esa dan berkemauan, serta berkemampuan untuk meneruskan cita-cita bangsa berdasarkan Pancasila. Penjelasan Pasal 9 UU No.4 Tahun 1979 tentang Kesejahteraan Anak.

Pemeliharaan anak juga mengandung arti sebuah tanggung jawab orang tua untuk mengawasi, memberikan pelayanan yang semestinya serta mencukupi kebutuhan hidup anak dari orangtuanya, kewajiban untuk melakukan pemeliharaan terhadap anak bersifat tetap sampai sianak mampu berdiri sendiri.

Akan tetapi realita yang terjadi sekarang adalah banyaknya anak yang mengalami kekerasan, menderita gizi buruk busung lapar dan hingga meningkatnya jumlah angka anak putus sekolah kondisi ini berada pada anak-anak korban perceraian kedua orang tua, dimana hak asuh anak yang berdasarkan putusan pengadilan berada pada ibu dan nafkah harus tetap diberikan oleh ayah namun ayah tidak pernah melakukan kewajibannya dengan baik apalagi kalau si ayah sudah menikah lagi. Banyak ayah memiliki kemampuan untuk menafkahi anaknya tapi setelah perceraian ia enggan untuk menafkahi anaknya, hal ini sebenarnya dapat diajukan gugatan, namun kenyataan yang terjadi di masyarakat banyak ibu mantan istri tidak melakukan karena, mereka enggan untuk berhubungan lagi dengan suaminya dan juga ada perasaan gengsi untuk meminta dari mantan suami walaupun untuk kepentingan anak mereka bersama. Fakta yang terjadi di masyarakat juga ayah akan lepas tangan dari anaknya jika hak asuh jatuh di tangan ibu, hal ini akan mengakibatkan kerugian pada si anak ketika si ayah melepaskan tanggungjawabnya sementara ibu seorang diri mencari nafkah dan memberikan kasih sayang akan terlihat ketidakadilan.

\section{P E N U T P}

Berdasarkan apa yang diuraikan maka dapat disimpulkan bahwa perceraian yang diakibatkan karena kekurangan istri berdasarkan ketentuan Undang-undang sangat merugikan perempuan karena yang diukur hanyalah kekurangan perempuan tanpa melihat kekurangan laki-laki, dan hak asuh anak berada dipihak istri, si suami tidak pernah melakukan kewajiban menafkahi anak secara baik, seperti yang diamanatkan oleh Undang-undang, menyebabkan terjadinya penelantaran terhadap anak. Anak tidak dapat bersekolah, harus bekerja di usia dini karena kurangnya biaya ekonomi untuk itu pemerintah harus mengambil kebijakan dengan cara: (a) Melakukan kontrol terhadap 
putusan pengadilan yang dikeluarkan khusus mengenai nafkah anak yang harus di penuhi oleh si ayah karena merupakan kewajibannya. Selama ini setelah putusan pengadilan yang menetapkan perceraian dan hak asuh anak pada ibu, ayah berkewajiban memberikan nafkah pada anak tersebut, namun setelah itu tidak pernah kewajiban ayah itu dilakukan dan pengadilan tidak pernah mengontrol apakah putusan perceraian yang diikuti dengan kewajiban nafkah anak itu dilakukan atau tidak. (b) Harus di buat sanksi yang tegas berupa hukuman badan atau denda yang besar bagi para ayah yang tidak melakukan kewajiban pemberian nafkah kepada anak yang berada di bawah pengasuhan ibu, dan bila si mantan suami ini dijerat dengan hukuman badan dan denda yang besar bisa saja mengurangi angka perceraian, karena apabila mantan suami diberi sanksi seperti itu, maka mantan suami ini akan berpikir beribu kali untuk menikah lagi karena konsekwensi yang nantinya akan diterima, apabila tidak melakukan kewajiban hukum terhadap anakanak dari mantan istrinya, dan hal ini juga dengan sendirinya dapat mengurangi kekerasan terhadap perempuan dan anak.

\section{DAFTAR PUSTAKA}

\section{Buku}

[1] Hurairah, A. (2006). Kekerasan Terhadap anak, Bandung: Penerbit Nuansa.

[2] Ramulyo, M. I. (2002). Hukum Perkawinan Islam, Jakarta : Bumi Aksara.

[3] Rofiq, Ahmad. (2013). Hukum Perdata Islam di Indonesia, Jakarta : Rajawali Pers.

[4] Syarifuddin, A. (2006). Hukum Perkawinan Islam di Indonesia, Jakarta: Prenada Media.

[5] Zein, S. E. M. (2004). Problematika Hukum Keluarga Islam Kontemporer, Jakarta: Prenada Media.

\section{Jurnal}

[6] Saifullah. (1999). "Problematika Anak dan Solusinya", Jurnal Mimbar Hukum, 42 (X). 